\title{
Impact of market anomalies on stock exchange: a comparative study of KSE and PSX
}

\author{
Sadia Anjum * (1)
}

\begin{abstract}
This paper serves the purpose of empirically investigating the impact of three market anomalies: day-of-the-week effect, weekend effect and monthly effect (January and July effects) on Pakistan stock market prior and after the establishment of PSX. The paper constructed multiple regression analysis employing dummy variables using least squares, ARCH and EGARCH-in-mean models. Breusch-Godfrey serial correlation LM test is used to check the serial correlation in the return series and Wald coefficient restriction test to evaluate joint significance of the dummy coefficients. However, Box-Jenkins (ARIMA) technique is used to evaluate the best fit of time series model to the past values of that time series. The results of the study reveal the highest Friday mean returns and lowest, but not negative Monday mean returns. Furthermore, the study indicates that December mean returns are high in Karachi Stock Exchange and March returns are high in the case of Pakistan Stock Exchange. This is the first study to evaluate the impact of three market anomalies prior and after the establishment of Pakistan Stock Exchange.
\end{abstract}

Keywords: Market anomalies, KSE, PSX, Stock returns, EMH, Systematic patterns

\section{Introduction}

Systematic patterns in financial market are irreconcilable to the efficient market hypothesis (EMH), ${ }^{1}$ as stock market returns can be predicted using these systematic patterns. These patterns influence the efficiency of stock market being about market anomalies. Among these systematic patterns, one of the common anomalies is dayof-the-week effect. The main conclusion in this regard is the highest Friday mean returns and lowest (usually negative) Monday mean returns [19, 27, 28, 39, 41]. French [27] stressed that Monday returns should be three times higher than the mean returns of other days as the time span between closing and starting of week is three days. Ferri et al. [25] found high Monday returns in the bill markets. Raj and Kumari [53] revealed positive Monday mean returns in Indian stock market. Choudhry [17] estimated highest mean Monday returns in the equity markets of India, Malaysia, Taiwan, South Korea, Indonesia,

\footnotetext{
*Correspondence: sadiaanjum88@gmail.com Department of Commerce and Finance, Government College University, Katchery Road, House\# 90, Gillani Street\# 4, Sadaqat Park Sanda Khurd, Lahore 54000, Pakistan
}

Philippines and Thailand. On the contrary, some studies also opposed the positive mean Monday returns. For instance, capital market of USA depicts the highest Friday, but the lowest and sometimes negative Monday returns [15]. Ajayi et al. [2] also found negative Monday returns in six EEEMs.

The existence of high mean returns in different days of the week has been confirmed by many studies. For instance, Dubois and Louvet [22] indicated highest returns in the closing of the week for Hong Kong, European countries and Canada. Agrawal and Tandon [1] also found highest mean returns in the closing of the week for 19 countries. Jaffe and Westerfield [33] found Tuesday effect in Australian and Japanese financial markets. Broca [12] indicated Wednesday effect in capital market of India. However, Malaikah [46] and Aybar [9] could not find day-of-the-week effect in Saudi Arabia, Turkey and Kuwait. Kato [36] indicated the highest Wednesday, but lowest Tuesday return in Japanese financial market.

\footnotetext{
${ }^{1}$ Efficient market hypothesis (EMH) asserts that share prices reflect all the information available to the general public.
} 
Nishat [48] identified anomalies such as size effect and liquidity effect in KSE. However, Hussain [31] and AlKhazali [6] found no systematic patterns for Pakistan and UAE capital markets, respectively.

Other market anomalies are related to weekend effect, month-of-the-year effect, etc. The main conclusion about month-of-the-year is that mean returns are high in January $[29,38,56]$. On the contrary, some research works also opposed this notion. For instance, Raj and Kumari [53] and Ignatius [32] observed no positive January effects for Indian stock market. Floros [26] and Olowe [50] observed no January effect for Greek and Nigerian stock markets. Some other studies concluded that January effect is related to the firm size; i.e. small capitalization firms perform better in January. Lee and Chang [44] observed firm size effect in Korean stock market. On the other hand, there are studies which did not conclude any weekend patterns. Depenchuk et al. [21] could not observe any weekend effect in Ukrainian stock market.

In line with these studies, the objective of the present study is to investigate the systematic patterns as day-ofthe-week effect, weekend effect and month-of-the-year effect in KSE and PSX as a comparative analysis. Moreover, the present study is a step forward to comprehend these systematic patterns and their impact on the informational efficiency of stock market.

\section{Pakistan Stock Exchange (PSX)}

Pakistan Stock Exchange was initiated on 11 January 2016 after integrating the three stock exchanges of Islamabad, Lahore and Karachi. In May 2017, Pakistan Stock Exchange is attributable to be a part of MSCI Emerging Market Index. There are nearly 400 brokerage houses and 21 asset management companies which are members of PSX.

\section{Theoretical framework}

In the literature, a substantial amount of theoretical discussion has been available that market anomalies become a cause of outperformance of stock market and affect its efficiency.

\section{Day-of-the-week effect}

Many hypotheses have been formulated to elaborate the day-of-the-week effect. Some of these are as follows:

\section{Settlement period hypothesis}

It states that return is high on pay-in days and low on payout days. But some researchers stand against this notion as different markets are likely to have different settlement dates. Agrawal and Tandon [1] found that settlement period is $6-15$ days in UK and 1 day in Hong Kong.

\section{Trading-/calendar-time hypothesis}

It is attributed that as there is a gap of 3 days from Friday closing to Monday opening, Monday mean returns should be three times higher than the returns of other week days. But different researchers noticed negative Monday returns. For instance, capital market of USA depicts the lowest and sometimes negative Monday returns [15]. Therefore, another hypothesis was considered that states that returns should be corresponding to the trading days. Rogalski [55] found negative returns during nontrading period.

\section{Retail investor trading hypothesis}

It asserts that trading activity of small and large firms is high and low on Monday, respectively [13].

\section{Month-of-the-year effect}

Many theories have been constructed in order to explain the month-of-the-year effect. Some of these are as follows:

\section{Tax-loss selling hypothesis}

It emphasizes that those firms which face a decline in stock in the last half part of the year usually gain high profit in January of the next year [11,35]. Lee and Chang [44], Lee [43] and Athannassakos [8] found positive January returns.

\section{Rebalancing hypothesis}

It deals with extravagant liquidity of the investors in the month of January, due to which January returns are high $[10,45,52]$.

\section{Other seasonal effects}

Besides daily and monthly effects, there are a number of other seasonal effects. Ariel [7] found that after holidays, returns are low. Dyl and Maberly [23]; Kolb and Rodriguez [40]; and Depenchuk et al. [21] found that mean returns are high around the end of the month. Lamb et al. [42] found that during spring time, mean returns are usually negative.

\section{Review of the literature}

There exists comprehensive literature that discerns the impact of market anomalies on the informational efficiency of the stock market. We discuss it as follows.

Ferri et al. [25] found irregular existence of the day-ofthe-week effect in the bill market by using three-month bills and employing Box-Jenkins time series techniques. 
Lee and Chang [44] examined the informational efficiency of Korean market and concluded that firm size effect is present only for trading period returns and January effect is present in non-trading period. Kato [36] investigated the stock market of Japan and concluded low Tuesday and high Wednesday returns by using simple regression model. Chang et al. [15] employed data from 2500 stocks of 24 different countries, among which 36 indices were of industrial groups and showed that day-of-the-week effect is not robust to the sample size and the error term adjustments in US stock market. Faff and Mckenzie [24] employed GARCH model which comprised an AR mean equation by using dummy variables and examined seven national markets (UK, Spain, Germany, USA, Switzerland, Japan and Australia) to investigate the impact of introduction of futures trading on the stock indices. The study followed Chang et al. [15] and concluded that trading of futures has no effect on seasonality of the stock returns. Ignatius [32] evaluated the relationship of the seasonality of Bombay Stock Exchange (BSE)-listed stock returns with the seasonality of New York Stock Exchange (NYSE)-listed stock returns. By employing regression analysis, the study concluded the similarity in the return patterns of both stock exchanges. The results indicated that December has the highest monthly returns and the fourth week of December has the highest weekly returns. Nishat and Mustafa [49] found the lowest returns on Monday and the highest returns on Friday in KSE. The study used simple mean and median approach and checked the volatility by using GARCH model.

Demirer and Karan [20] examined daily, start-ofthe-month and mid-month effects in Istanbul Stock Exchange (ISE). The results concluded the absence of Monday effect, and, in contrast, the presence of high Friday returns. Moreover, no evidence is found for mid-ofthe-month and start-of-the-month effects. Ajayi et al. [2] examined day-of-the-week effect in 11 Eastern European emerging markets (EEEMs) by using classical time series analysis and augmented Dickey-Fuller test for stationarity. The empirical results found positive Monday returns in five of EEEMs and negative Monday returns in remaining six of EEEMs. Al-Khazali [6] examined UAE capital markets to empirically evaluate the impact of thin trading on the day-of-the-week effect by employing stochastic dominance approach. The study emphasized that when measurement biases which arouse from thin trading process were removed, then the day-of-the-week effect disappeared automatically. The study followed Ajayi et al. [2]. Al-Khazali et al. [5] employed stochastic dominance approach to examine the Saturday effect in the stock markets of Kuwait, Saudi Arabia and Bahrain by considering thin trading process. The study emphasized as
Al-Khazali [6] did, that when measurement biases which arouse from thin trading process were removed, Saturday effect disappeared automatically. Silvapulle [56] examined some OECD countries and emerging economies to evaluate the monthly market anomaly. The study employed Franses test, Beaulieu-Miron test and Canova and Hansen [14] LM tests and found January effect exists in many of these stock markets.

Raj and Kumari [53] examined day-of-the-week effect, weekend effect and January/April effect in Indian stock market by employing different statistical methods. The study concluded that January effect is absent and Monday returns are positive in Indian stock market. Depenchuk et al. [21] examined weekend, January and turn-of-themonth (TOM) effects in the stock and bond markets of Ukraine. The study provided the evidence for the nonexistence of weekend effect and January effect by employing Wilcoxon sign-ranked tests, parametric, nonparametric ${ }^{2}$ tests as $t$ test and Chi-square, whereas turn-of-the-month effect exists. Floros [26] investigated Greek stock market to evaluate the impact of trading month and monthly effects by utilizing an ordinary least square (OLS) model. The study provided the evidence for high April returns. In context of trading month effect, the study concluded that over the first 15 days of the month, the mean returns are high. Olowe [50] suggested the nonexistence of monthof-the-year effect in Nigerian stock market by utilizing EGARCH-in-mean model. Philpot and Peterson [51] concluded a literature review to conclude that research works pre-2003 years observed positive Friday and negative Monday returns, but research works after 2003 years observed that now this effect is reversing, vanishing or transferring to other week days. Nippani and Greenhut [47] followed Philpot and Peterson [51] and concluded that Canadian markets provided evidence for the existence of positive Friday and negative Monday returns, but after 1988, this effect reversed. Tilica and Oprea [57] followed Nippani and Greenhut [47] and found the nonexistence of positive Friday mean returns in Romanian stock market. Keef et al. [37] by employing panel regression and considering data of 50 countries, concluded that Monday bad effect and non-Monday bad effect decline over time. Al-Ississ [4] found a positive trend in the stock market during the month of Ramadan and a negative trend during Ashura related to the Shia community of a country. Javaria and Hassan [34] revealed the nonexistence of herd behaviour in the daily and monthly stock returns of Karachi Stock Exchange. Akhtar and Khan [3] analysed the volatility of KSE-100 index. By using ARCH

\footnotetext{
${ }^{2}$ Nonparametric tests refer to the statistical approach used when data or returns series are not required to fit a normal distribution.
} 
and GARCH models, the study suggested that weekly, daily and monthly stock returns show volatility, stationarity and nonnormal distribution of KSE returns.

\section{Methods}

This section discussed data and methodologies adopted in this study.

\section{Data}

The data set is comprised of monthly, daily and weekly returns of KSE and PSX. The KSE data set consists of the period from 02 January 2004 to 10 January 2016. As Pakistan Stock Exchange was established on 11 January 2019, PSX data set is comprised of the period from 11 January 2016 to 30 April 2019. The data about PSX and KSE were collected from the official Web site of PSX. To calculate the market anomalies, closing returns are used. ${ }^{3}$

\section{Modelling framework}

This study evaluates the impact of market anomalies with dummy variables in a multiple regression analysis using least squares, $\mathrm{ARCH}$ and EGARCH-in-mean models. Breusch-Godfrey serial correlation LM test is used to check the serial correlation in the return series. ${ }^{4}$ Stock returns may have nonsymmetric properties, and due to time-varying variance in the series, result would be in the form of inefficient estimates. This study resolves this problem by constructing ARCH and EGARCH-inmean models. Wald test has been employed to evaluate the joint significance of all dummies/anomalies coefficients. Furthermore, Box-Jenkins (ARIMA) technique is employed by the study to evaluate the best fit of time series model to the past values of that time series.

The tests employed by the study are connected with parametric and nonparametric groups in order to examine different hypotheses mentioned above. The daily returns are being calculated as follows:

$$
R_{t}=\ln \left(\frac{l_{t}}{l_{(t-1)}}\right) \times 100
$$

where $I_{t}$ refers to the index price and $R_{t}$ refers to the stock returns on any day $(t)$.

\section{Day-of-the-week effect}

The study constructed the following equation to evaluate the day-of-the-week effect by employing five dummies from Monday to Friday:

\footnotetext{
${ }^{3}$ Missing values are omitted from the analysis.

4 It evaluates the existence of serial correlation that has not been included in a proposed model structure and which, if exist, would mean that incorrect and inefficient estimations would be drawn from other tests.
}

$$
R_{t}=\omega_{1} D_{1}+\omega_{2} D_{2}+\omega_{3} D_{3}+\omega_{4} D_{4}+\omega_{5} D_{5}+\phi_{t}
$$

where $R_{t}$ is the return as discussed in Eq. (1). $\omega_{1}, \omega_{2}, \omega_{3}, \ldots$, $\omega_{5}$ are dummy coefficients which indicate mean returns of each day of the week. $D_{1}, D_{2}, D_{3}, \ldots, \mathbf{D}_{5}$ are dummy variables for each day of the week, which are either 0 or $1 . \Phi_{t}$ is the white noise or error term for any day $(t)$.

$$
\operatorname{Hypothesis}\left(H_{0}\right): \omega_{1}=\omega_{2}=\omega_{3}=\omega_{4}=\omega_{5}=0
$$

$H_{0}$ emphasizes that all the days of the week have joint/ similar return patterns. If the empirical results reject this hypothesis, it would mean that there exists seasonality in the stock market. The study also tests the significance of daily returns, i.e. $\omega_{1}, \omega_{2}, \omega_{3}, \ldots, \omega_{5}$, to evaluate to what extent they differ from zero. The signs of these coefficients indicate whether their difference is zero, positive or negative.

Weekend effect The study empirically evaluated these two hypotheses to check the impact of weekend effect:

Trading-time hypothesis This hypothesis emphasizes that Monday mean returns are higher than other days of the week:

$$
R_{t}=\psi_{1}+\psi_{2} D_{2 t-1}+\psi_{3} D_{3 t-1}+\psi_{4} D_{4 t-1}+\psi_{5} D_{5 t-1}+\phi_{t}
$$

where $R_{t}$ is the mean return on any day $(t) . \psi_{1}$ is the expected Monday mean returns; $\psi_{2}, \psi_{3}, \psi_{4}$ and $\psi_{5}$ are dummy coefficients and represent the difference between expected Monday mean returns and the returns on other days of the week. $D_{2}, D_{3}, D_{4}$ and $D_{5}$ are dummy variables for each day of the week, which are either 0 or 1 :

$$
\text { Hypothesis }\left(H_{0}\right): \psi_{2}=\psi_{3}=\psi_{4}=\psi_{5}=0 .
$$

If this hypothesis is significant, it means that there exists a variation between Monday returns and returns on other days of the week.

Calendar-time hypothesis This hypothesis emphasizes that returns on Monday are three times higher than the returns on other days of the week.

$$
R_{t=\frac{1}{3}} \chi_{1}+x_{2} D_{2 t}+\chi_{3} D_{3 t}+\chi_{4} D_{4 t}+\chi_{5} D_{5 t}+\phi_{t}
$$

where $R_{t}$ are mean returns on any day $(t) . X_{1}$ is the expected one-third mean Monday returns. $X_{2}, X_{3}, X_{4}$ and $X_{5}$ are dummy coefficients and show the difference between mean returns of other days of the week and onethird of Monday returns. $D_{2}, D_{3}, D_{4}$ and $D_{5}$ are dummy variables, which are either 0 or 1 . 
Table 1 LM test for serial correlation

\begin{tabular}{|c|c|c|c|c|c|c|c|}
\hline \multicolumn{4}{|l|}{ KSE } & \multicolumn{4}{|l|}{ PSX } \\
\hline Variables & Coefficients & $t$-statistics & Probability & Variables & Coefficients & $t$-statistics & Probability \\
\hline D1 & 3.143523 & $2.92 \mathrm{E}-13$ & $0.0000^{* * *}$ & D1 & 1.074341 & $6.60 E-14$ & $0.0000^{* * *}$ \\
\hline D2 & 1.696332 & $-1.57 \mathrm{E}-14$ & $0.0000^{* * *}$ & D2 & 7.365634 & $4.53 \mathrm{E}-15$ & $0.0000^{* * *}$ \\
\hline D3 & 8.536229 & -0.793516 & $0.0025^{* * *}$ & D3 & 7.584364 & $4.66 \mathrm{E}-14$ & $0.0000^{* * *}$ \\
\hline D4 & 0.104725 & 0.009734 & $0.0022^{* * *}$ & D4 & 0.042336 & -0.258312 & $0.0003^{* * *}$ \\
\hline D5 & 7.936333 & $-7.37 \mathrm{E}-14$ & $0.0000^{* * *}$ & D5 & 0.006111 & -0.037283 & $0.0003^{* * *}$ \\
\hline F-statistic & 546339.5 & Prob. F(2,321) & $0.0000^{* * *}$ & F-statistic & 1086.793 & Prob. F(2,321) & $0.0000^{* * *}$ \\
\hline Obs* $R^{2}$ & 3699.456 & Prob. Chi square(2) & $0.0000^{* * *}$ & $\mathrm{Obs}^{*} R^{2}$ & 285.7934 & Prob. Chi square(2) & $0.0000^{* * *}$ \\
\hline \multicolumn{4}{|l|}{$R^{2}: 0.996621$} & \multicolumn{4}{|l|}{$R^{2}: 0.871321$} \\
\hline
\end{tabular}

*Denotes significance at 10 per cent, ${ }^{* *}$ significance at 5 per cent and ${ }^{* * *}$ significance at 1 per cent

Hypothesis $\left(H_{0}\right): \Upsilon_{2}=\Upsilon_{3}=\Upsilon_{4}=\Upsilon_{5}=0$

If this hypothesis is significant, it means that there exists a variation between one-third of Monday mean returns and returns on other days of the week.

This study investigated the calendar-time and trading-time hypotheses for KSE and PSX as Pakistan Stock Exchange now has fully electronic trading system with $\mathrm{T}+3$ settlement period.

\section{Month-of-the-year/January effect/portfolio rebalancing hypothesis}

To evaluate the January effect and month-of-the-year effect, the study used the following equation:

$$
R_{t}=\delta_{1}+\delta_{i} D_{i t}+\phi_{t}
$$

where $R_{t}$ represents the monthly return on any month $(t)$. $\delta_{1}$ is the expected January mean returns. $\delta_{i t}$ is the dummy coefficient and shows the difference between expected January returns and returns in other months. $D_{i t}$ is the dummy variable for each month-of-the-year, which is either 0 or 1 :

Hypothesis $\left(H_{0}\right): \delta_{2}=\delta_{3}=\delta_{4}=\delta_{5}=, \ldots,=\delta_{12}=0$.

If the empirical results reject this hypothesis, it means that there exists a variation between expected January mean returns and returns in other months of the year.

July effect/tax-loss selling hypothesis The study utilized this test to examine the tax-loss selling hypothesis in KSE and PSX:

$$
R_{t}=\delta_{1}+\delta_{i} D_{i t}+\phi_{t}
$$

where $R_{t}$ is the monthly return on any month $(t) . \delta_{1}$ is the expected July mean returns. $\delta_{i t}$ is dummies coefficient and shows the difference between expected July returns and returns in other months. $D_{i t}$ is the dummy variable for each month-of-the-year, which is either 0 or 1 .

$$
\text { Hypothesis }\left(H_{0}\right): \delta_{2}=\delta_{3}=\delta_{4}=\delta_{5}=, \ldots,=\delta_{12}=0 .
$$

The rejection of this hypothesis means that there exists a variation between expected July returns and returns in other calendar months.

In Pakistan, financial year is closed on June 30. Therefore, the study evaluated July effect. This study examined tax-loss selling hypothesis and portfolio rebalancing hypothesis in the context of KSE and PSX.

\section{Results}

This section is related to the empirical estimations of the study. These estimations are as follows:

\section{Weekday effects}

The weekday effect estimation is of two types: (a) day-ofthe-week effect and (b) weekend Effect.

Table 1 shows the results for serial correlation and concludes that there is no serial correlation in KSE and PSX daily return series. Tables 2, 3 and 4 indicate the day-ofthe-week and weekend results for KSE and PSX. The $p$ values show that all differentiated dummies are significant at 1 per cent level of significance for KSE and PSX, which means that daily returns are different on each day of the week. Results further indicate that Friday returns are higher as compared to other week days and Monday returns are lowest, but not negative. The lowest Monday mean returns provide evidence that investors hold on the information from Friday closing to Monday opening and show unwillingness to invest on Monday opening due to the accumulation of the information. Moreover, the results negate the existence of trading-time and calendartime hypotheses in both KSE and PSX. Furthermore, the results indicate that as we move from Monday to Friday, returns show an increasing trend. These results are 
Table 2 Day-of-the-week/weekend effect regression analysis

\begin{tabular}{|c|c|c|c|c|c|c|c|}
\hline \multicolumn{4}{|l|}{ KSE } & \multicolumn{4}{|l|}{ PSX } \\
\hline Variables & Coefficients & $t$-statistics & Probability & Variables & Coefficients & t-statistics & Probability \\
\hline D1 & 6412.848 & 34.68671 & $0.0000^{* * *}$ & D1 & 80.79697 & 167.7882 & $0.0000^{* * *}$ \\
\hline D2 & 6418.529 & 34.71743 & $0.0000^{* * *}$ & D2 & 80.86152 & 166.5757 & $0.0000^{* * *}$ \\
\hline D3 & 6430.383 & 34.75814 & $0.0000^{* * *}$ & D3 & 80.87077 & 166.5458 & $0.0000^{* * *}$ \\
\hline D4 & 6430.406 & 34.75826 & $0.0000^{* * *}$ & D4 & 81.14183 & 167.0932 & $0.0000^{* * *}$ \\
\hline D5 & 6433.508 & 34.77503 & $0.0000^{* * *}$ & D5 & 81.18300 & 167.1780 & $0.0000^{* * *}$ \\
\hline \multicolumn{4}{|l|}{$R^{2}: 0.601601$} & \multicolumn{4}{|l|}{$R^{2}: 0.630315$} \\
\hline
\end{tabular}

*Denotes significance at 10 per cent, ${ }^{* *}$ significance at 5 per cent and ${ }^{* * *}$ significance at 1 per cent

Table 3 Day-of-the-week/weekend effect ARCH model

\begin{tabular}{|c|c|c|c|c|c|c|c|}
\hline \multicolumn{4}{|l|}{ KSE } & \multicolumn{4}{|l|}{ PSX } \\
\hline Variables & Coefficients & z-statistics & Probability & Variables & Coefficients & z-statistics & Probability \\
\hline D1 & 8120.535 & 48.11137 & $0.0000^{* * *}$ & D1 & 79.00206 & 426.6306 & $0.0000^{* * *}$ \\
\hline D2 & 8174.623 & 48.47277 & $0.0000^{* * *}$ & $\mathrm{D} 2$ & 79.13822 & 487.0593 & $0.0000^{* * *}$ \\
\hline D3 & 8180.017 & 48.23690 & $0.0000^{* * *}$ & D3 & 79.15198 & 370.2650 & $0.0000^{* * *}$ \\
\hline D4 & 8185.717 & 48.59850 & $0.0000^{* * *}$ & D4 & 79.25223 & 426.2000 & $0.0000^{* * *}$ \\
\hline D5 & 8240.789 & 49.00542 & $0.0000^{* * *}$ & D5 & 79.44504 & 401.3138 & $0.0000^{* * *}$ \\
\hline \multicolumn{4}{|l|}{$R^{2}: 0.641000$} & \multicolumn{4}{|c|}{$R^{2}: 0.561623$} \\
\hline
\end{tabular}

*Denotes significance at 10 per cent, ${ }^{* *}$ significance at 5 per cent and ${ }^{* * *}$ significance at 1 per cent

Table 4 Day-of-the-week/weekend effect EGARCH-in-mean model

\begin{tabular}{|c|c|c|c|c|c|c|c|}
\hline \multicolumn{4}{|l|}{ KSE } & \multicolumn{4}{|l|}{ PSX } \\
\hline Variables & Coefficients & z-statistics & Probability & Variables & Coefficients & z-statistics & Probability \\
\hline \multicolumn{8}{|c|}{ Mean equation } \\
\hline D1 & 6803.431 & 46.86957 & $0.0000^{* * *}$ & D1 & 79.00906 & 504.6870 & $0.0000^{* * *}$ \\
\hline D2 & 6899.661 & 46.97317 & $0.0000^{* * *}$ & $\mathrm{D} 2$ & 79.34979 & 525.4269 & $0.0000^{* * *}$ \\
\hline D3 & 6919.985 & 46.93577 & $0.0000^{* * *}$ & D3 & 79.35385 & 472.3930 & $0.0000^{* * *}$ \\
\hline D4 & 6946.823 & 47.03507 & $0.0000^{* * *}$ & D4 & 79.84702 & 536.2018 & $0.0000^{* * *}$ \\
\hline D5 & 6948.214 & 47.23603 & $0.0000^{* * *}$ & D5 & 79.97299 & 381.4094 & $0.0000^{* * *}$ \\
\hline \multicolumn{8}{|c|}{ Variance equation } \\
\hline$C(6)$ & 11.53601 & 91.19732 & $0.0000^{* * *}$ & $C(6)$ & -0.711973 & -3.984881 & $0.0001^{* * *}$ \\
\hline$C(7)$ & 1.999259 & 10.21317 & $0.0000^{* * *}$ & $C(7)$ & 1.327377 & 5.426888 & $0.0000^{* * *}$ \\
\hline$C(8)$ & -0.163404 & -0.770643 & $0.0020^{* * *}$ & $C(8)$ & 0.140330 & 1.026331 & $0.0034^{* * *}$ \\
\hline$C(9)$ & 0.202226 & 27.98723 & $0.0000^{* * *}$ & $C(9)$ & 0.735166 & 8.669524 & $0.0000^{* * *}$ \\
\hline \multicolumn{4}{|l|}{$R^{2}: 0.711973$} & \multicolumn{4}{|l|}{$R^{2}: 0.703321$} \\
\hline
\end{tabular}

*Denotes significance at 10 per cent, ${ }^{* *}$ significance at 5 per cent and ${ }^{* * *}$ significance at 1 per cent

consistent with Cornell [18], Keim and Stambaugh [39], Hess [30] and French [27].

The study examined the joint significance of null hypothesis $\left(H_{0}\right)$ coefficients by employing Wald coefficient restriction test. Table 5 shows the results.
Wald coefficient results indicate that $H_{0}$ can be rejected, which means that returns pattern is different for each day of the week.

Table 6 shows the results of Box-Jenkins (ARIMA) model for daily KSE and PSX returns. 
Table 5 Wald coefficient restriction test

\begin{tabular}{|c|c|c|c|c|c|c|c|}
\hline \multicolumn{4}{|l|}{ KSE } & \multicolumn{4}{|l|}{ PSX } \\
\hline Test statistics & Values & $d f$ & Prob. & Test statistics & Values & $d f$ & Prob. \\
\hline F-statistics & 1203.168 & $(1,3707)$ & $0.0000^{* * *}$ & F-statistics & 31952.30 & $(1,323)$ & $0.0000^{* * *}$ \\
\hline Chi square & 1203.168 & 1 & $0.0000^{* * *}$ & Chi square & 31952.30 & 1 & $0.0000^{* * *}$ \\
\hline
\end{tabular}

${ }^{*}$ Denotes significance at 10 per cent, ${ }^{* *}$ significant at 5 per cent and ${ }^{* * *}$ significance at 1 per cent

Table 6 Box-Jenkins (ARIMA) model

\begin{tabular}{|c|c|c|c|c|c|c|c|}
\hline \multicolumn{4}{|l|}{ KSE } & \multicolumn{4}{|l|}{ PSX } \\
\hline Variables & Coefficients & $t$-statistics & Probability & Variables & Coefficients & $t$-statistics & Probability \\
\hline$A R(1)$ & 0.534855 & 15.81380 & $0.0000^{* * *}$ & $A R(1)$ & 0.198326 & -0.763118 & $0.0020^{* * *}$ \\
\hline$M A(1)$ & 0.287635 & 15.49531 & $0.0000^{* * *}$ & $M A(1)$ & 0.026308 & 0.106040 & $0.0016^{* * *}$ \\
\hline \multicolumn{4}{|l|}{$R^{2}: 0.767193$} & \multicolumn{4}{|c|}{$R^{2}: 0.619880$} \\
\hline
\end{tabular}

*Denotes significance at 10 per cent, ${ }^{* *}$ significance at 5 per cent and ${ }^{* * *}$ significance at 1 per cent

Table 7 Month-of-the-year-effect regression analysis

\begin{tabular}{|c|c|c|c|c|c|c|c|}
\hline \multicolumn{4}{|l|}{ KSE } & \multicolumn{4}{|l|}{ PSX } \\
\hline Variables & Coefficients & $t$-statistics & Prob. & Variables & Coefficients & $t$-statistics & Prob. \\
\hline D1 & 5698.071 & 4.380539 & $0.0000^{* * *}$ & D1 & 81.08000 & 32.86167 & $0.0000^{* * *}$ \\
\hline D2 & 5747.237 & 4.418337 & $0.0000^{* * *}$ & D2 & 83.08000 & 23.80989 & $0.0000^{* * *}$ \\
\hline D3 & 5922.063 & 4.552739 & $0.0000^{* * *}$ & D3 & 86.41000 & 24.76423 & $0.0000^{* * *}$ \\
\hline D4 & 6019.219 & 4.778235 & $0.0000^{* * *}$ & D4 & 81.62000 & 23.39147 & $0.0000^{* * *}$ \\
\hline D5 & 6045.493 & 4.981651 & $0.0000^{* * *}$ & D5 & 82.39000 & 33.39261 & $0.0000^{* * *}$ \\
\hline D6 & 6295.250 & 4.946485 & $0.0000^{* * *}$ & D6 & 80.35500 & 32.56782 & $0.0000^{* * *}$ \\
\hline D7 & 6463.674 & 4.811326 & $0.0000^{* * *}$ & D7 & 79.48000 & 32.21319 & $0.0000^{* * *}$ \\
\hline D8 & 6627.255 & 4.933090 & $0.0000^{* * *}$ & D8 & 79.34000 & 22.73804 & $0.0000^{* * *}$ \\
\hline D9 & 6688.571 & 4.978732 & $0.0000^{* * *}$ & D9 & 76.06000 & 21.79803 & $0.0000^{* * *}$ \\
\hline D10 & 6733.637 & 4.863404 & $0.0000^{* * *}$ & D10 & 80.55000 & 23.08481 & $0.0000^{* * *}$ \\
\hline D11 & 6779.469 & 5.046393 & $0.0000^{* * *}$ & D11 & 78.45000 & 22.48298 & $0.0000^{* * *}$ \\
\hline D12 & 6946.599 & 5.170799 & $0.0000^{* * *}$ & $\mathrm{D} 12$ & 81.15000 & 23.25677 & $0.0000^{* * *}$ \\
\hline \multicolumn{4}{|l|}{$R^{2}: 0.632505$} & \multicolumn{4}{|l|}{$R^{2}: 0.640641$} \\
\hline
\end{tabular}

*Denotes significance at 10 per cent, ${ }^{* *}$ significance at 5 per cent and ${ }^{* * *}$ significance at 1 per cent

ARIMA results provide evidence for the best fit of time series model to the past values of the time series for both KSE and PSX.

\section{Month-of-the-year effect}

Tables 7, 8 and 9 represent the monthly results for KSE and PSX. Table 10 represents the results of LM test for serial correlation.

These results conclude the nonexistence of serial correlation for both KSE and PSX monthly return series.

The results show that $\mathrm{p}$ values are significant at 1 per cent for KSE and PSX. KSE monthly results provide the evidence that December returns are highest and January returns are lowest, but not negative. As we move from January to December, stock returns show an increasing trend. These results are consistent with Raj and Kumari [53] and Raj and Thurston [54]. However, PSX monthly returns provide evidence for the highest March returns. PSX returns show mixed variation from January to December throughout the selected period of the study. These results are consistent with Chatterjee and Maniam [16] and Keim [38]. Both KSE and PSX results provide evidence for the nonexistence of portfolio rebalancing and tax-loss selling hypotheses in Pakistan stock markets. The results negate the existence of July effect. 
Table 8 Month-of-the-year-effect ARCH model

\begin{tabular}{|c|c|c|c|c|c|c|c|}
\hline \multicolumn{4}{|l|}{ KSE } & \multicolumn{4}{|l|}{ PSX } \\
\hline Variables & Coefficients & $z$-statistics & Prob. & Variables & Coefficients & $z$-statistics & Prob. \\
\hline D1 & 7270.041 & 6.521786 & $0.0000^{* * *}$ & D1 & 82.80017 & 5.431564 & $0.0000^{* * *}$ \\
\hline D2 & 7490.977 & 10.73030 & $0.0000^{* * *}$ & D2 & 78.34584 & 6.362622 & $0.0000^{* * *}$ \\
\hline D3 & 7807.625 & 7.628923 & $0.0000^{* * *}$ & D3 & 88.68887 & 8.382517 & $0.0000^{* * *}$ \\
\hline D4 & 8252.198 & 6.546838 & $0.0000^{* * *}$ & D4 & 78.60784 & 7.473884 & $0.0000^{* * *}$ \\
\hline D5 & 8254.069 & 4.815544 & $0.0000^{* * *}$ & D5 & 79.34000 & 5.373895 & $0.0000^{* * *}$ \\
\hline D6 & 8602.036 & 4.709142 & $0.0000^{* * *}$ & D6 & 76.06000 & 4.579236 & $0.0000^{* * *}$ \\
\hline D7 & 8800.311 & 4.451400 & $0.0000^{* * *}$ & D7 & 78.45000 & 6.824774 & $0.0000^{* * *}$ \\
\hline D8 & 8811.439 & 4.976618 & $0.0000^{* * *}$ & D8 & 80.55000 & 5.732573 & $0.0000^{* * *}$ \\
\hline D9 & 8974.967 & 5.268697 & $0.0000^{* * *}$ & D9 & 81.15000 & 4.573157 & $0.0000^{* * *}$ \\
\hline D10 & 9197.953 & 5.434362 & $0.0000^{* * *}$ & D10 & 83.08000 & 7.436683 & $0.0000^{* * *}$ \\
\hline D11 & 9311.450 & 5.712891 & $0.0000^{* * *}$ & D11 & 86.41000 & 5.384288 & $0.0000^{* * *}$ \\
\hline D12 & 9656.938 & 6.496169 & $0.0000^{* * *}$ & D12 & 81.62000 & 7.362437 & $0.0000^{* * *}$ \\
\hline \multicolumn{4}{|l|}{$R^{2}: 0.747725$} & \multicolumn{4}{|l|}{$R^{2}: 0.711335$} \\
\hline
\end{tabular}

*Denotes significance at 10 per cent, ${ }^{* *}$ significance at 5 per cent and ${ }^{* * *}$ significance at 1 per cent

Table 9 Month-of-the-year-effect EGARCH-in-mean model

\begin{tabular}{|c|c|c|c|c|c|c|c|}
\hline \multicolumn{4}{|l|}{ KSE } & \multicolumn{4}{|l|}{ PSX } \\
\hline Variables & Coefficients & $z$-statistics & Probability & Variables & Coefficients & z-statistics & Probability \\
\hline \multicolumn{8}{|c|}{ Mean equation } \\
\hline D1 & 5893.742 & 5.830880 & $0.0000^{* * *}$ & D1 & 81.08000 & 13.91640 & $0.0000^{* * *}$ \\
\hline D2 & 5970.061 & 6.360438 & $0.0000^{* * *}$ & D2 & 82.39000 & 3.086888 & $0.0000^{* * *}$ \\
\hline D3 & 6149.421 & 6.677541 & $0.0000^{* * *}$ & D3 & 88.35500 & 45.89546 & $0.0000^{* * *}$ \\
\hline D4 & 6559.880 & 6.509776 & $0.0000^{* * *}$ & D4 & 79.48000 & 3.945738 & $0.0000^{* * *}$ \\
\hline D5 & 6836.392 & 5.566956 & $0.0000^{* * *}$ & D5 & 79.34000 & 0.028830 & $0.0000^{* * *}$ \\
\hline D6 & 6903.227 & 6.433449 & $0.0000 * * *$ & D6 & 76.06000 & 0.027805 & $0.0000^{* * *}$ \\
\hline D7 & 7384.314 & 5.725763 & $0.0000^{* * *}$ & D7 & 78.45000 & 0.028679 & $0.0000^{* * *}$ \\
\hline D8 & 7750.419 & 6.488386 & $0.0000^{* * *}$ & D8 & 80.55000 & 0.029447 & $0.0000^{* * *}$ \\
\hline D9 & 7825.489 & 6.458064 & $0.0000^{* * *}$ & D9 & 81.15000 & 0.029666 & $0.0000^{* * *}$ \\
\hline D10 & 8572.228 & 6.714530 & $0.0000^{* * *}$ & D10 & 83.08000 & 0.030372 & $0.0000^{* * *}$ \\
\hline D11 & 8758.445 & 6.248054 & $0.0000^{* * * *}$ & D11 & 86.41000 & 0.031589 & $0.0000^{* * *}$ \\
\hline D12 & 8788.759 & 6.435179 & $0.0000^{* * *}$ & D12 & 81.62000 & 0.004957 & $0.0000^{* * *}$ \\
\hline \multicolumn{8}{|c|}{ Variance equation } \\
\hline$C(13)$ & 15.70508 & 3.054986 & $0.0023^{* * *}$ & $C(13)$ & 1.113112 & 0.008011 & $0.0036^{* * *}$ \\
\hline$C(14)$ & 1.753017 & 2.224279 & $0.0026^{* * *}$ & $C(14)$ & 0.010000 & 0.000625 & $0.0025^{* * *}$ \\
\hline$C(15)$ & -0.000878 & -0.001449 & $0.0028^{* * *}$ & $C(15)$ & 0.010000 & 0.000639 & $0.0005^{* * *}$ \\
\hline$C(16)$ & -0.031455 & -0.110375 & $0.0012^{* * *}$ & $C(16)$ & 0.010000 & 8.17E-05 & $0.0009^{* * *}$ \\
\hline \multicolumn{4}{|l|}{$R^{2}: 0.672356$} & \multicolumn{4}{|l|}{$R^{2}: 0.611729$} \\
\hline
\end{tabular}

***Denotes significance at 1 per cent, ${ }^{* *}$ significance at 5 per cent and *significance at 10 per cent

The study tested the joint significance of $H_{0}$ coefficients by utilizing Wald coefficient restriction test. Table 11 shows the results. $p$ values are significant at 1 per cent for both KSE and PSX, so $H_{0}$ can be rejected, which means that monthly returns are significantly different from each other.
Table 12 shows the results of Box-Jenkins (ARIMA) model for monthly KSE and PSX returns.

ARIMA results provide evidence for the best fit of time series model to the past values of the time series for both KSE and PSX. 
Table 10 LM test for serial correlation

\begin{tabular}{|c|c|c|c|c|c|c|c|}
\hline \multicolumn{4}{|l|}{ KSE } & \multicolumn{4}{|l|}{ PSX } \\
\hline Variables & Coefficients & $t$-statistics & Prob. & Variables & Coefficients & $t$-statistics & Prob. \\
\hline D1 & 5.444643 & $-1.60 E-15$ & $0.0000^{* * *}$ & D1 & 1.446752 & $4.09 E-15$ & $0.0000^{* * *}$ \\
\hline D2 & 1.765673 & $-5.00 \mathrm{E}-15$ & $0.0000^{* * *}$ & D2 & 3.236244 & 0.000000 & $0.0000^{* * *}$ \\
\hline D3 & 1.313464 & $3.73 E-15$ & $0.0000^{* * *}$ & D3 & 2.325447 & 0.000000 & $0.0000^{* * *}$ \\
\hline D4 & 1.346425 & $-3.88 \mathrm{E}-16$ & $0.0000^{* * *}$ & D4 & 3.462563 & 0.000000 & $0.0000^{* * *}$ \\
\hline D5 & 358.9395 & -1.018026 & $0.0001^{* * *}$ & D5 & 2.023264 & $5.82 \mathrm{E}-15$ & $0.0000^{* * *}$ \\
\hline D6 & 12.03772 & 0.034041 & $0.0029^{* * *}$ & D6 & 2.134622 & $-6.11 E-16$ & $0.0000^{* * *}$ \\
\hline D7 & 7.815374 & $-2.22 \mathrm{E}-16$ & $0.0000^{* * *}$ & D7 & 1.353473 & $3.87 \mathrm{E}-15$ & $0.0000^{* * *}$ \\
\hline D8 & 8.854663 & $2.50 E-16$ & $0.0000^{* * *}$ & D8 & 1.352626 & -0.024961 & $0.0024^{* * *}$ \\
\hline D9 & 4.484742 & $1.27 \mathrm{E}-15$ & $0.0000^{* * *}$ & D9 & 3.463732 & -0.006133 & $0.0037^{* * *}$ \\
\hline D10 & 8.235744 & $-2.34 \mathrm{E}-15$ & $0.0000^{* * *}$ & D10 & 2.464647 & 0.000000 & $0.0000^{* * *}$ \\
\hline D11 & 5.054744 & $-1.44 E-15$ & $0.0000^{* * *}$ & D11 & 4.273462 & 0.000000 & $0.0000^{* * *}$ \\
\hline D12 & 1.476748 & $4.16 \mathrm{E}-15$ & $0.0000^{* * *}$ & D12 & 3.462263 & 0.000000 & $0.0000^{* * *}$ \\
\hline F-statistic & 1139.986 & Prob. $F(2,167)$ & $0.0000^{* * *}$ & F-statistic & 0.006807 & Prob. $F(2,2)$ & $0.0002^{* * *}$ \\
\hline $\begin{array}{l}\text { Obs }^{*} R^{2} \\
R^{2}: 931752\end{array}$ & 168.6472 & Prob. Chi square(2) & $0.0000^{* * *}$ & $\begin{array}{l}\mathrm{Obs}^{*} R^{2} \\
R^{2}: 0.676123\end{array}$ & 0.108171 & Prob. Chi square(2) & $0.0004^{* * *}$ \\
\hline
\end{tabular}

*Denotes significance at 10 per cent, ${ }^{* *}$ significance at 5 per cent and ${ }^{* * *}$ significance at 1 per cent

Table 11 Wald coefficient restriction test

\begin{tabular}{|c|c|c|c|c|c|c|c|}
\hline \multicolumn{4}{|l|}{ KSE } & \multicolumn{4}{|l|}{ PSX } \\
\hline Test statistics & Values & $d f$ & Prob. & Test statistics & Values & $d f$ & Prob. \\
\hline F-statistics & 19.18912 & $(1,171)$ & $0.0000^{* * *}$ & F-statistics & 1079.889 & $(1,4)$ & $0.0000^{* * *}$ \\
\hline Chi square & 19.18912 & 1 & $0.0000^{* * *}$ & Chi square & 1079.889 & 1 & $0.0000^{* * *}$ \\
\hline
\end{tabular}

*Denotes significance at 10 per cent, ${ }^{* *}$ significance at 5 per cent and ${ }^{* * *}$ significance at 1 per cent

Table 12 Box-Jenkins (ARIMA) model

\begin{tabular}{|c|c|c|c|c|c|c|c|}
\hline \multicolumn{4}{|l|}{ KSE } & \multicolumn{4}{|l|}{ PSX } \\
\hline Variables & Coefficients & $t$-statistics & Probability & Variables & Coefficients & $t$-statistics & Probability \\
\hline$A R(1)$ & 0.907484 & 3.926412 & $0.0001^{* * *}$ & $\operatorname{AR}(1)$ & 0.118593 & 0.638310 & $0.0033^{* * *}$ \\
\hline$M A(1)$ & 0.128063 & 0.561834 & $0.0000^{* * *}$ & $\mathrm{MA}(1)$ & 0.941298 & 22.37745 & $0.0000^{* * *}$ \\
\hline \multicolumn{4}{|l|}{$R^{2}: 0.98194$} & \multicolumn{4}{|l|}{$R^{2}: 0.774913$} \\
\hline
\end{tabular}

*Denotes significance at 10 per cent, ${ }^{* *}$ significance at 5 per cent and ${ }^{* * *}$ significance at 1 per cent

\section{Discussion}

This study examined only a few hypotheses. Future research can be conducted to examine other hypotheses as well, i.e. settlement period hypothesis and retail investor trading hypothesis.

Systematic patterns in the stock market cause unexpected profit earnings for the investors. Policymakers can make suitable policies for efficient stock market by examining the systematic trends in the stock returns.

\section{Conclusion}

The study concluded about daily returns that Friday returns are highest as compared to the other days of the week and Monday returns are lowest, but not negative. So, trading-time and calendar-time hypotheses do not exist in both KSE and PSX. Monthly returns indicate the nonexistence of January and July effects in the cases of KSE and PSX. In KSE, monthly returns are high in December, and in PSX, monthly returns are high in March. So, portfolio rebalancing and tax-loss selling hypotheses do not exist in both KSE and PSX. Both 
the markets do not provide any evidence of July effect. Breusch-Godfrey serial correlation LM test results conclude the nonexistence of serial correlation in KSE and PSX returns, and Box-Jenkins (ARIMA) model provides evidence for the best fit of time series model to the past values of the time series.

\section{Abbreviations}

KSE: Karachi Stock Exchange; PSX: Pakistan Stock Exchange; EMH: efficient market hypothesis; EEEMs: Eastern European emerging markets; AR: autoregressive; BSE: Bombay Stock Exchange; NYSE: New York Stock Exchange; ISE: Istanbul Stock Exchange; TOM: turn-of-the-month; OLS: ordinary least square.

\section{Acknowledgements}

I verify that this article "Impact of Market Anomalies on Stock Exchange: A Comparative Study of KSE and PSX" is my original work, has not received any prior publication and is not under consideration for publication elsewhere.

\section{Authors' contributions}

The author read and approved the final manuscript.

\section{Funding}

This research did not receive any specific grant from funding agencies in the public, commercial or not-for-profit sectors.

\section{Availability of data and material}

Will be provided on request.

\section{Competing interests}

The author declares that there are no competing interests.

Received: 6 August 2019 Accepted: 18 December 2019 Published: 7 January 2020

\section{References}

1. Agrawal A, Tandon K (1994) Anomalies or illusions? Evidence from stock markets in eighteen countries. J Int Money Finance 13:83-106

2. Ajayi RA, Mehdian S, Perry MJ (2004) The day-of-the-week effect in stock returns: further evidence from Eastern European emerging markets. Emerg Mark Finance Trade 40(4):53-62

3. Akhtar S, Khan NU (2016) Modeling volatility on the Karachi stock exchange, Pakistan. J Asia Bus Stud 10(3):253-275

4. Al-Ississ M (2015) The holy day effect. J Behav Exp Finance 5:60-80

5. Al-Khazali O, Zoubi TA, Koumanakos EP (2010) The Saturday effect in emerging stock markets: a stochastic dominance approach. Int J Emerg Mark 5(2):227-246

6. Al-Khazali OM (2008) The impact of thin trading on day-of-the-week effect: evidence from the United Arab Emirates. Rev Account Finance 7(3):270-284

7. Ariel RA (1990) High stock returns before holidays: existence and evidence on possible causes. J Finance 45:1611-1626

8. Athannassakos G (1997) Firm size, stock return seasonality, and the trading pattern of individual investors: the Canadian experience. J Invest 6(3):75-86

9. Aybar C (1992) Descriptive analysis of stock return behavior in an emerging market: the case of Turkey. Ph.D. Dissertation, Ohio State University

10. Bensman M (1997) Putting the market on the couch. Inst Invest 31(1):133-135

11. Branch B (1977) A tax-loss trading rule. J Bus 50(2):198-207

12. Broca D (1992) Day of the week patterns in the Indian stock market. Decision 19:57-64

13. Brooks R, Kim H (1997) The individual investor and the weekend effect: a re-examination with intraday data. Q Rev Econ Finance 37(3):725-737
14. Canova F, Hansen BE (1995) Are seasonal patterns constant over time? A test for seasonal stability. J Bus Econ Stat 13:237-252

15. Chang EC, Pinegar JM, Ravichandran R (1993) International evidence on the robustness of the day-of-the-week effect. J Financial and Quant Anal 28(4):497-513

16. Chatterjee A, Maniam B (1997) Market anomalies revisited. J Appl Bus Res 13(4):47-56

17. Choudhry T (2000) Day of the week effect in emerging Asian stock markets: evidence from the GARCH model. Appl Financ Econ 10:235-242

18. Cornell B (1985) The weekly pattern in stock returns: cash versus futures: a note. J Finance 40:583-588

19. Cross F (1973) The behavior of stock prices on Friday and Monday. Financ Ana J 29:67-70

20. Demirer R, Karan MB (2002) An investigation of the day-of-theweek effect on stock returns in Turkey. Emerg Mark Finance Trade 38(6):47-77

21. Depenchuk IO, Compton WS, Kunkel RA (2010) Ukrainian financial markets: an examination of calendar anomalies. Managerial Finance 36(6):502-510

22. Dubois M, Louvet $P$ (1996) The day-of-the-week-effect: the international evidence. J Bank Finance 20(9):1463-1484

23. Dyl E, Maberly E (1988) A possible explanation of the weekend effect. Financ Anal J 44:83-84

24. Faff RW, Mckenzie MD (2002) The impact of stock index futures trading on daily returns seasonality: a multicountry study. J Bus 75(1):95-125

25. Ferri MG, Goldstein SJ, Oberhelman HD (1984) A second look at day-ofthe-week effects in treasury bill returns. Q J Bus Econ 23(4):46-56

26. Floros C (2008) The monthly and trading month effects in Greek stock market returns: 1996-2002. Managerial Finance 34(7):453-464

27. French K (1980) Stock returns and the weekend effects. J Financ Econ 8:55-69

28. Gibbons MR, Hess P (1981) Day of the week effect and asset returns. J Bus 54:579-596

29. Gultekin M, Gultekin N (1983) Stock market seasonality: international evidence. J Financ Econ 12:469-481

30. Hess P (1981) Day of the week effects and asset returns. J Bus 54(2):579-595

31. Hussain F (1999) The day of the week effect in the Pakistani equity market: an investigation. Lahore J Econ 5(1):93-98

32. Ignatius $R$ (1998) The Bombay stock exchange: seasonalities and investment opportunities. Managerial Finance 24(3):52-61

33. Jaffe J, Westerfield R (1985) The weekend effect in common stock market returns: the international evidence. J Finance 40:433-454

34. Javaria Z, Hassan A (2015) An examination of herding behavior in Pakistan stock market. Int J Emerg Mark 10(3):474-490

35. Johnston K, Cox D (1996) The influence of tax-loss selling by individual investors in explaining the January effect. Q J Bus Econ 35(2):14-20

36. Kato K (1990) Weekly patterns in Japanese stock returns. Manage Sci 36(9):1031-1043

37. Keef SP, Khaled M, Zhu H (2009) The dynamics of the Monday effect in international stock indices. Int Rev Financ Anal 18(3):125-133

38. Keim D (1983) Size-related Anomalies and stock return seasonality. J Financ Econ 12:13-32

39. Keim DB, Stambaugh RF (1984) A further investigation of the weekend effect in stock returns. J Finance 39:819-835

40. Kolb R, Rodriguez R (1987) Friday the thirteenth: part VII—a note. J Finance 42:1385-1387

41. Lakonishok J, Smidt S (1987) Are seasonal anomalies real? A ninety years perspective. Rev Financ Stud 1:403-425

42. Lamb RP, Zuber RA, Gandar JM (2004) Don't lose sleep on it: a reexamination of the daylight savings time anomaly. Appl Financ Econ 14:443-446

43. Lee I (1992) Stock market seasonality: some evidence from the Pacific Basin countries. J Bus Finance Account 19(2):199-209

44. Lee KY, Chang CS (1988) Anomalies in the stock returns over trading and nontrading periods: further evidence in the Korean stock market. Q J Bus Econ 27(2):139-161

45. Ligon J (1997) A simultaneous test of competing theories regarding the January effect. J Financ Res 20(1):13-32 
46. Malaikah SJ (1990) A study of stock market behavior and its policy implications. Ph.D. Dissertation, Michigan State University

47. Nippani S, Greenhut JG (2011) Reversal of the weekend effect in Canada: an empirical analysis. Managerial Finance 37(9):840-854

48. Nishat M (1999) The institutional development and share prices in Pakistan. Unpublished Ph.D. disseration, Aukland Business School, University of Aukland

49. Nishat M, Mustafa K (2002) Anomalies in Karachi stock market: day of the week effect. Bangladesh Dev Stud 28(3):55-64

50. Olowe RA (2009) Stock return volatility, global financial crisis and the monthly seasonal effect on the Nigerian stock exchange. Int Rev Bus Res Papers 5(4):426-447

51. Philpot J, Peterson CA (2011) A brief history and recent developments in day-of-the-week effect literature. Managerial Finance 37(9):808-816

52. Porter D, Powell G, Weaver D (1996) Portfolio rebalancing, institutional ownership, and the small-firm January effect. Rev Financ Econ 5(1):19-29
53. Raj M, Kumari D (2006) Day-of-the-week and other market anomalies in the Indian stock market. Int J Emerg Mark 1(3):235-246

54. Raj M, Thurston D (1994) January or April? Tests of the turn-of-the-year effect in the New Zealand stock market. Appl Econ Lett 1:81-83

55. Rogalski R (1984) New findings regarding day-of-the-week returns over trading and non-trading periods: a note. J Finance 39:1603-1614

56. Silvapulle $P(2004)$ Testing for seasonal behavior of monthly stock returns: evidence from international markets. Q J Bus Econ 43(1/2):93-109

57. Tilica EV, Oprea D (2014) Seasonality in the Romanian stock market: the day-of-the-week effect. Procedia Econ Finance 15:704-710

\section{Publisher's Note}

Springer Nature remains neutral with regard to jurisdictional claims in published maps and institutional affiliations.

\section{Submit your manuscript to a SpringerOpen ${ }^{\circ}$ journal and benefit from:}

- Convenient online submission

- Rigorous peer review

- Open access: articles freely available online

- High visibility within the field

- Retaining the copyright to your article

Submit your next manuscript at $\gg$ springeropen.com 